\title{
Dinosaurs nesting on tidal flats
}

\author{
N. López-Martínez ${ }^{\mathrm{a}, *}$, J.J. Moratalla $^{\mathrm{b}}$, J.L. Sanz ${ }^{\mathrm{b}}$ \\ ${ }^{a}$ Departamento de Paleontología, Facultad de Ciencias Geológicas, Universidad Complutense, 28040 Madrid, Spain \\ ${ }^{\mathrm{b}}$ Unidad de Paleontología, Convenio U.A.M.-IBERDROLA, Dto. Biología, Fac. Ciencias, Universidad Autónoma, 28049 Madrid, Spain
}

Received 8 October 1998; received in revised form 24 January 2000; accepted for publication 26 January 2000

\begin{abstract}
The discovery of a dinosaur clutch in Upper Cretaceous tidal flat deposits in the Tremp Formation in Biscarri, Isona (Lleida, Spain), provides insight into the mode of life of some dinosaurs. The clutch occurs in grey marls that were originally waterlogged, muddy sediments. The seven elongated eggs are parallel to each other and with their long axis almost vertically oriented. A mound-nest is inferred in contrast to hole-nest described so far for similar eggshell types. The permeability of the eggshell (oospecies Megaloolithus siruguei) was highly enhanced by a braided network of multicanaliculate pore canals. The nest style, eggshell porosity and tidal flat environment point to a periaquatic habitat for these dinosaurs. A modern analogue occurs in crocodiles, alligators and some birds living in periaquatic environments, with nesting on plant-mounds above waterlogged soils or even on floating vegetation.
\end{abstract}

Keywords: dinosaurs; eggs; nests; Spanish Pyrenees; tidal flats; Upper Cretaceous

\section{Introduction}

Evidence for the dinosaur mode of life is rarely found in the fossil record, and thus habitat hypotheses have been supported by indirect arguments. Sauropods were classically regarded as aquatic dinosaurs, having been considered too heavy for walking on land. They were depicted submerged in shallow water with snorkel-like nares (Hay, 1908). Such a 'hippo-like' mode of life was widely accepted also for hadrosaurs until the early 1970s. During the 'Dinosaur Renaissance' of the 1970s, some authors rejected the aquatic lifestyle hypothesis, based on morphofunctional analyses that suggested terrestrial habits (Bakker, 1971; Coombs,

\footnotetext{
* Corresponding author.

E-mail address: lopezmar@geo.ucm.es (N. López-Martínez)
}

1974). This view is now largely accepted by most dinosaur palaeontologists.

Most of the fossil evidence for dinosaur nesting habits is found in deposits from terrestrial habitats (flood-plains, palaeosols, abandoned channel-fills deposits; Erben et al., 1979; Iatzoura et al., 1991; Cousin et al., 1994). However, because the amniotic egg is adapted for terrestrial conditions, most aquatic amniote vertebrates nest on dry land; thus, the terrestrial settings for dinosaur nests are not neccessarily evidence for a terrestrial habitat for dinosaurs.

There are in fact some indications for a periaquatic habitat for some dinosaurs. Dinosaur bones are frequently found in shallow marine and estuarine deposits (Weishampel and Horner, 1990; Schwimmer, 1997 and references cited therein). They are usually interpreted as being transported from terrestrial habitats, but it may also indicate 
a periaquatic habitat. The findings of articulate parts, half-parts and also near-complete dinosaur skeletons preserved in marine shelves, scavenged by sharks and even encrusted with oysters are rather frequent (Horner, 1979; Fiorello, 1990; Schwimmer, 1997; Canudo et al., 1998); this would be exceptional for fully terrestrial organisms.

Moreover, some sedimentary environments in which sauropod bones and tracks are found connect this group to aquatic environments (Dodson, 1990; Lockley et al., 1994). There are also some cases of dinosaur clutches in marginal aquatic palaeoenvironments, such as lake shores (Sahni et al., 1994) and beach deposits (Sanz et al., 1995). These discoveries suggest an aquatic mode of life for these dinosaurs, but do not prove it. Some terrestrial species, such as modern terrestrial emus (Dromaeus novaehollandiae), may nest occasionally on lake shores when the substrate is dry (De Deckker, 1988).

We report here a dinosaur clutch found in an ancient tidal flat environment from the Upper Cretaceous of Biscarri (near Isona, Spain, Fig. 1). These eggs belong to the oospecies Megaloolithus siruguei, currently found in grey marls from aquatic palaeoenvironments. This discovery is the first autochthonous dinosaur clutch recovered from a water-saturated environment. Nest settings in coastal waterlogged soils are not found in terrestrial species, and thus it constitutes palaeobiological evidence indicating a periaquatic habitat for these dinosaurs.

\section{Geological setting}

The Biscarri clutch was preserved in its original position at the top of a $80 \mathrm{~m}$ thick succession of grey marls, shales, lignites and limestones from the lower Member of the Tremp Formation named La Posa Grey Marls (Isona, Lleida, Fig. 1; Liebau, 1973). Some lignite beds have been exploited by mining works in this section, a few metres below the interval represented in the Fig. 1. The continental red beds of the Tremp Formation in the Isona area reach up to $900 \mathrm{~m}$ in thickness, of which La Posa Grey Marls made up the lower $120 \mathrm{~m}$. These deposits formed part of the Late Cretaceous regres- sive cycle filling the South Pyrenean foredeep basin.

The La Posa Grey Marls are underlain and interbedded with marine sandstones from the Aren Formation exposed along the periclinal closure of the Isona Anticline. Near Isona, the Aren Formation consists of medium to coarse grained tabular sandstones with sharp contacts, and containing large-scale sigmoidal cross-bedding indicative of tidal influence (Nagtegaal et al., 1983; López Martínez and Ardèvol, 1999). The contact with the overlying La Posa Grey Marls is marked by a rudist bed mainly composed of Radiolitella pulchellus. The two related formations have been interpreted as a lagoon-barrier island depositional system dissected by tidal inlets, receiving significant freshwater inputs from the continent (Fig. 2) (Liebau, 1971, 1973; Nagtegaal et al., 1983; DíazMolina, 1987).

The dating of the La Posa Grey Marls relies in biostratigraphic data. The Biscarri section is situated between two marine levels containing corals and the rudist Hippuritella castroi (Liebau, 1971). These rudist levels have been correlated with the lower Gansserina gansseri zone indicating a Late Campanian age (Vicens et al., 1999; Ardèvol et al., 2000). The upper rudist-bearing level, near the top of the Biscarri section (Fig. 1) has also yielded planktonic foraminifera (Globotruncanella havanensis, Globotruncana arca and Rosita fornicata) and benthic foraminifera (five species of Bolivinoides, such as B. peterssoni-laevigatus and B. draco miliaris) (Liebau, 1973). Between these two clear marine intercalations, the section contains transitional and freshwater deposits with oyster beds, coal seams and peritidal limestones bearing ostracods and charophyte remains. The presence of the charophytes Amblyochara c. mucronata and Peckychara sertulata in the grey marls of this section and the absence of Septorella indicate a Late Campanian age (Feist and Colombo, 1983; Riveline et al., 1996) after recalibration of the Campanian-Maastrichtian boundary (Obradovich, 1993; Gradstein et al., 1995). Palynomorphs are abundant along the whole section, with ferns and palms dominant (De Porta et al., 1985).

The sediment containing the dinosaur clutch is 


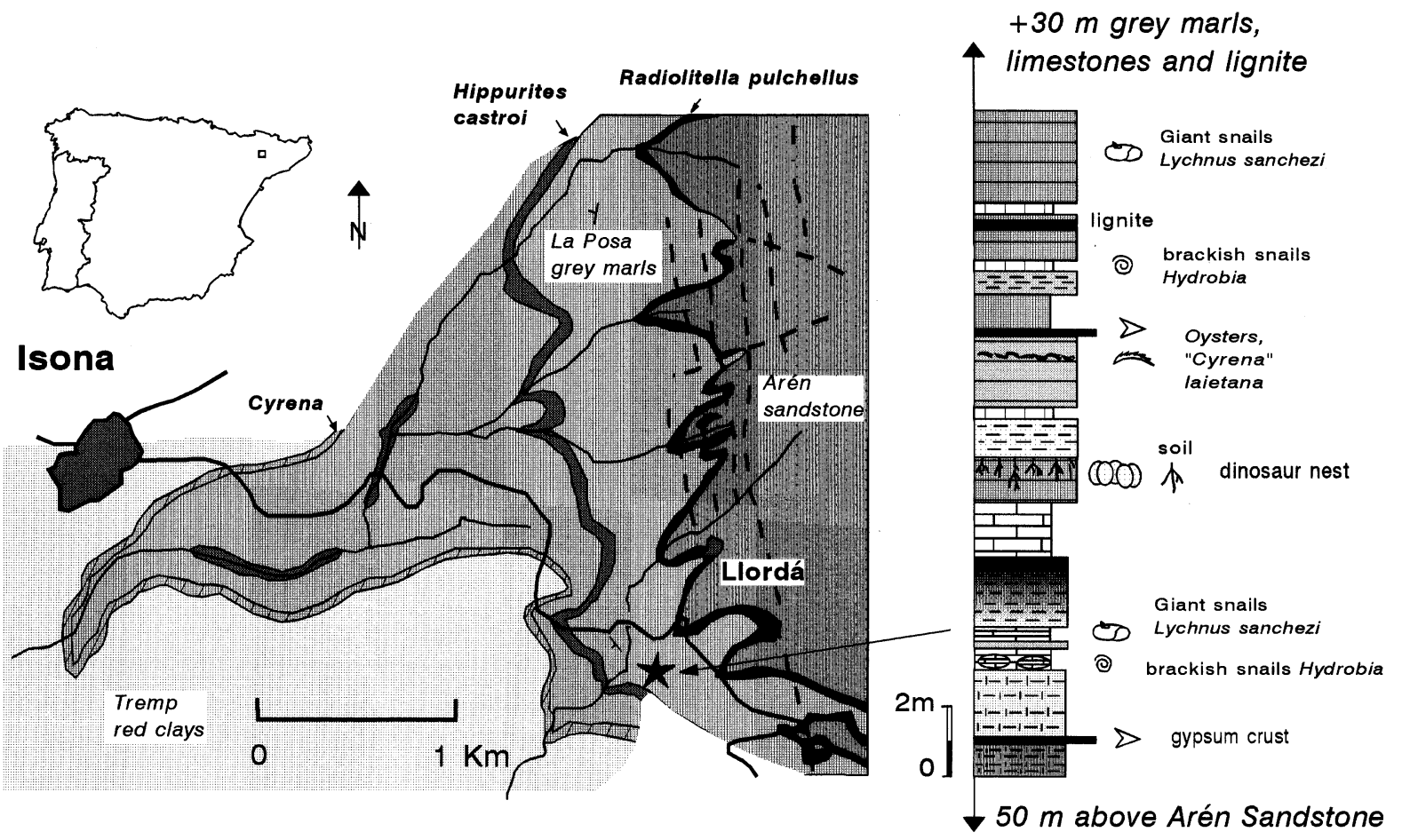

Fig. 1. Map and log of the Biscarri section in La Posa Grey Marls, lower Member of the Tremp Formation, along the periclinal contour of the Isona anticline. The Aren Formation is situated about $50 \mathrm{~m}$ below. The position of the upper Hippuritella castroi level is indicated on the map. The situation of the clutch at the top of a grey marl bed is shown, perforated by traces of roots probably from aquatic plants. Map modified from Liebau (1973).

a homogeneous grey-coloured marl with ironencrusted root casts (rhizoliths). The marls around the eggs contained plant debris, crustaceans (decapods, euryhaline ostracods), molluscs, fish bones, ray teeth, an ankylosaur tooth and diverse types of eggshell fragments. The eggs are covered by the same types of grey marl that underlie them, and contain framboidal pyrite encrusting the interior side of the eggshells. The marls bear iron-reduced colours and locally contain bioturbation structures (burrows) preserved as siderite concretions that are diagenetic products of the first-formed hydroxides (Ai-Agha et al., 1995). Leaching features, nodulization or mottling (marmorization) are absent, indicating that the profile was within the phreatic nape, below the vadose zone. These features indicate water-saturated sediments in a reducing coastal environment, from peritidal swamp (lignites and limestones) to tidal flats (grey marls), comparable to the modern coastal series of mud flats and salt marsh (Verger, 1968; Pye et al., 1990; Allen and Pye, 1992; Ai-Agha et al., 1995).

A hydromorphic soil developed after the nest was laid, since the eggs were perforated by the root traces passing through them. The rusty-coloured rhizoliths, reaching about $1 \mathrm{~m}$ deep and 1$2 \mathrm{~cm}$ in diameter, are evenly spaced and gently curved but do not show frequent branching. They are coated with hydrated iron (limonite) and gypsum crystals, which occasionally also encrust lignites and mollusc shells. The iron-coated root traces, and the absence of nodulization, leaching horizon, shrinkage and brecciation, indicate waterlogged gley pedogenetic processes (Retallack, $1988,1990)$. The gypsum is early diagenetic, linked to local pyrite hydration in a gley-type hydromor- 

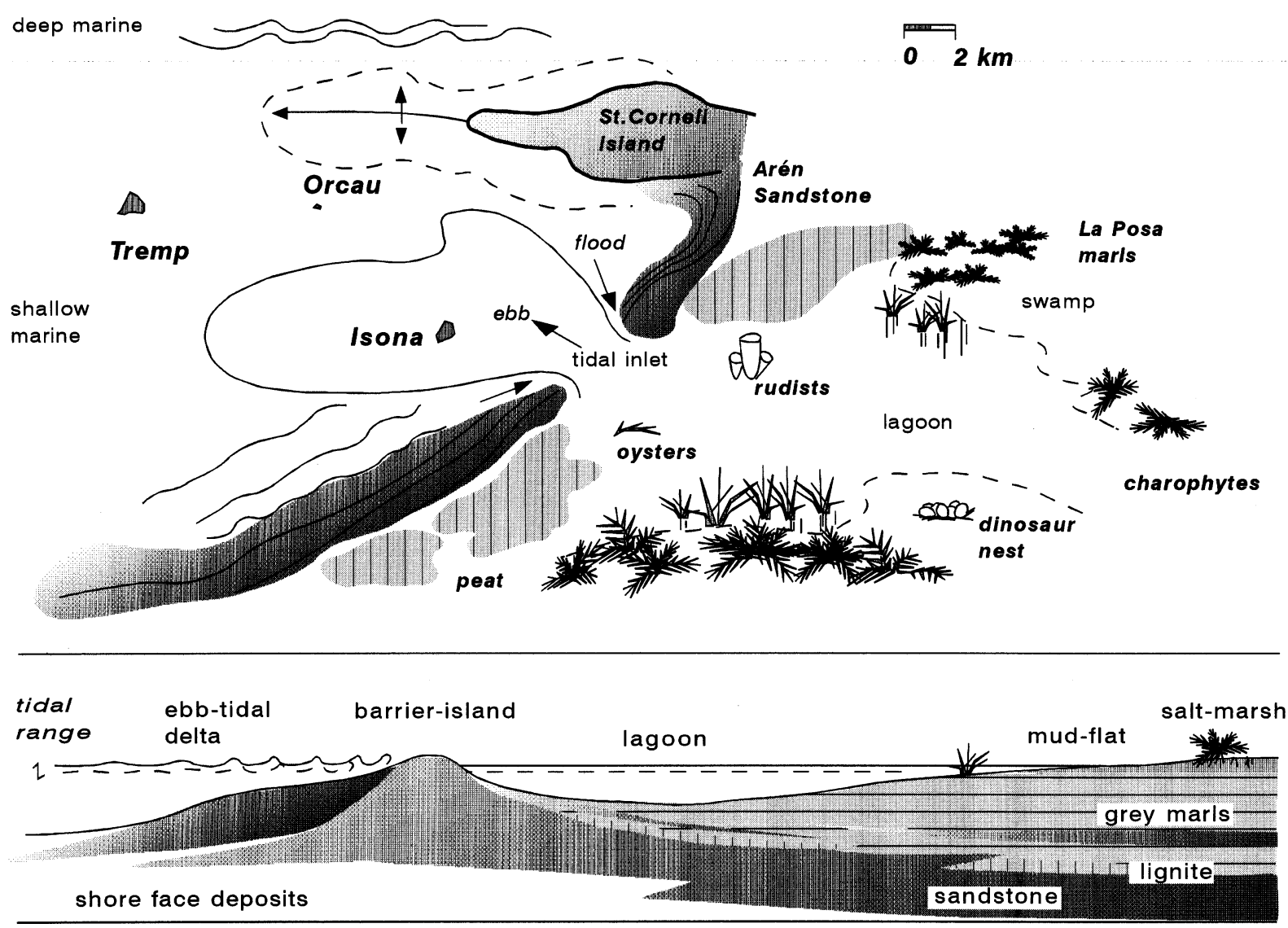

Fig. 2. Palaeogeographic reconstruction and cross-section during the late Campanian in the Southern Pyrenees. La Posa Grey Marls correspond to the deposits of lagoon and peritidal swamps. The Aren Formation corresponds to deposits of mesotidal barrier islands system and ebb-tidal delta [according to Nagtegaal et al. (1983) and Díaz-Molina (1987)]. The position of the Biscarri dinosaur clutch corresponds to tidal mud-flat deposits. After flooding and burial of the nest, plants from the supratidal salt marsh prograded over the area to produce the root traces.

phic soil (hydrated pyrite when combined with calcite produces limonite and calcium sulphate; Nicolas, 1949; Ai-Agha et al., 1995).

From these data it can be inferred that the Biscarri dinosaur clutch was deposed in waterlogged tidal flat sediments from a perilagoonal environment. After the eggs were laid in the tidal flat, the nest was flooded and covered with mud and subsequently perforated by the growth of plant roots associated to the prograding salt-marsh (Duchaufour, 1960; Freytet and Plaziat, 1982; Rahmani, 1988).

Scattered eggshells from hatched eggs of the same egg-type as those of the Biscarri clutch have been reported in sediments a few metres above the clutch (Moratalla, 1993). A concentration of dinosaur eggshells has been reported $5 \mathrm{~km}$ north of Biscarri, in a similar sedimentary facies (Rosell, 1967). Eggshells were also found in the neighbouring Barranco de la Posa lignites (Erben et al., 1979). Moreover, bones of sauropod dinosaurs have been found at the neighbouring Torra mine. In addition, probable dinosaur footprints have been reported in the area (Díaz-Molina, 1987; unpublished findings of Eduard Domínguez, Isona). These discoveries document the existence 
of stable dinosaur populations living in La Posa lagoon during the Late Campanian.

\section{Description of the clutch}

The clutch contains seven incomplete dinosaur eggs. Recent erosion has removed the top of the eggs and we do not know if more eggs were originally present (Fig. 3). The preserved clutch is about $90 \mathrm{~cm}$ long and about $40 \mathrm{~cm}$ wide. Five out of the seven eggs lie in a single plane, and the other two eggs are in a slightly higher plane (Fig. 3). The eggs are arranged in a longitudinal pattern, with five eggs aligned to each other (numbers 1, 2, 3, 5 and 7 in Fig. 3) and two other eggs lying parallel. This evidence is consistent with either both oviducts laying the eggs or with a single oviduct laying the eggs in two phases. The first hypothesis agrees better with the preserved state of the clutch and with other clutches observed in the area (Sanz et al., 1995).

A sediment of similar texture and composition surrounds and fills the eggs and clutch (Fig. 1). Lack of clear margins around the clutch, and the vertical disposition of the eggs (Fig. 3) suggest that the nesting structure was not a buried hole. Moreover, the sediment indicates deposition in water-saturated conditions, and wet mud is an unsuitable substratum for nest burial because it impedes air conductance. Therefore, this nest setting is not compatible with the burial-nesting pattern attributed to sauropods (Erben et al., 1979; Kerourio, 1981; Williams et al., 1984; Cousin et al., 1994; Sanz et al., 1995). The waterlogged conditions of the ground and the arrangement of the eggs instead suggest that the Biscarri clutch was placed on the surface of the substratum. The eggs were probably laid on a plant mound because the vertically oriented eggs would be not stable unless a soft material supported them.

Dinosaur clutches similar to that described here have not been reported before. Nests with seven or eight eggs from Southern France (Kerourio, 1981; Cousin et al., 1994; Garcia, 1998) have been attributed to a hole nesting with the eggs arranged at different levels. Other clutches show a circular pattern (Zhao, 1979; Horner, 1987; Sahni et al., 1994).

The eggs are elongated in shape, with an estimated maximum length of about $25 \mathrm{~cm}$ and $18 \mathrm{~cm}$ width. An exact reconstruction of the egg shape, either ellipsoid or ovoid, is precluded because of the preservation state of the eggs. However, the bimodal distribution pattern of the eggshell thickness (Fig. 4) is more consistent with a symmetrical ellipsoid shape. The thickest eggshell fragments correspond to both poles and the thinnest ones to the equatorial area. Ovoid eggs would present a more continuous distribution of eggshell thickness. An ellipsoid-shaped egg is also congruent with a simultaneous production of eggs. An ovoid, asymmetrical shape would indicate a sequential production of eggs, such as in the case of the avian reproductive apparatus (Varricchio et al., 1997).

The eggshell is well preserved, with no signs of erosion, internal surfaces slightly encrusted with pyrite framboids, and empty pore channels. Eggshell thickness, external ornamentation and shape of the shell crystalline units (Fig. 5) identify the eggshells as Megaloolithus siruguei (VianeyLiaud et al., 1994). This oospecies name includes both spherical and elongated eggs (Williams et al., 1984; Vianey-Liaud et al., 1994; Garcia, 1998). The surface is nodular, with relatively rounded or polygonal nodes (compactituberculate ornamentation). The pore openings are subrounded in shape, with an estimated pore density of about $120-150 / \mathrm{cm}^{2}$. No reabsorption craters have been found in the mammillary cores at the base of the shell units along the inner surface, indicating that these eggs were not hatched. This interpretation is also supported by the preserved structure of the clutch, since the hatchling would have disturb the ordered, vertical, closely packed eggs.

The crystal units are spherulitic, high, narrow, well individualized and not fused (dinosauroidspherulitic basic type, and discretipherulitic morphotype). They show convex growth lines (Fig. 5b) and a sweeping extinction pattern under the polarizing microscope. The eggshell thickness varies between 2.3 and $3.2 \mathrm{~mm}$. The pore canals are relatively straight, with a relatively constant diameter along their length. A braided network of transverse canals connects the primary canals 

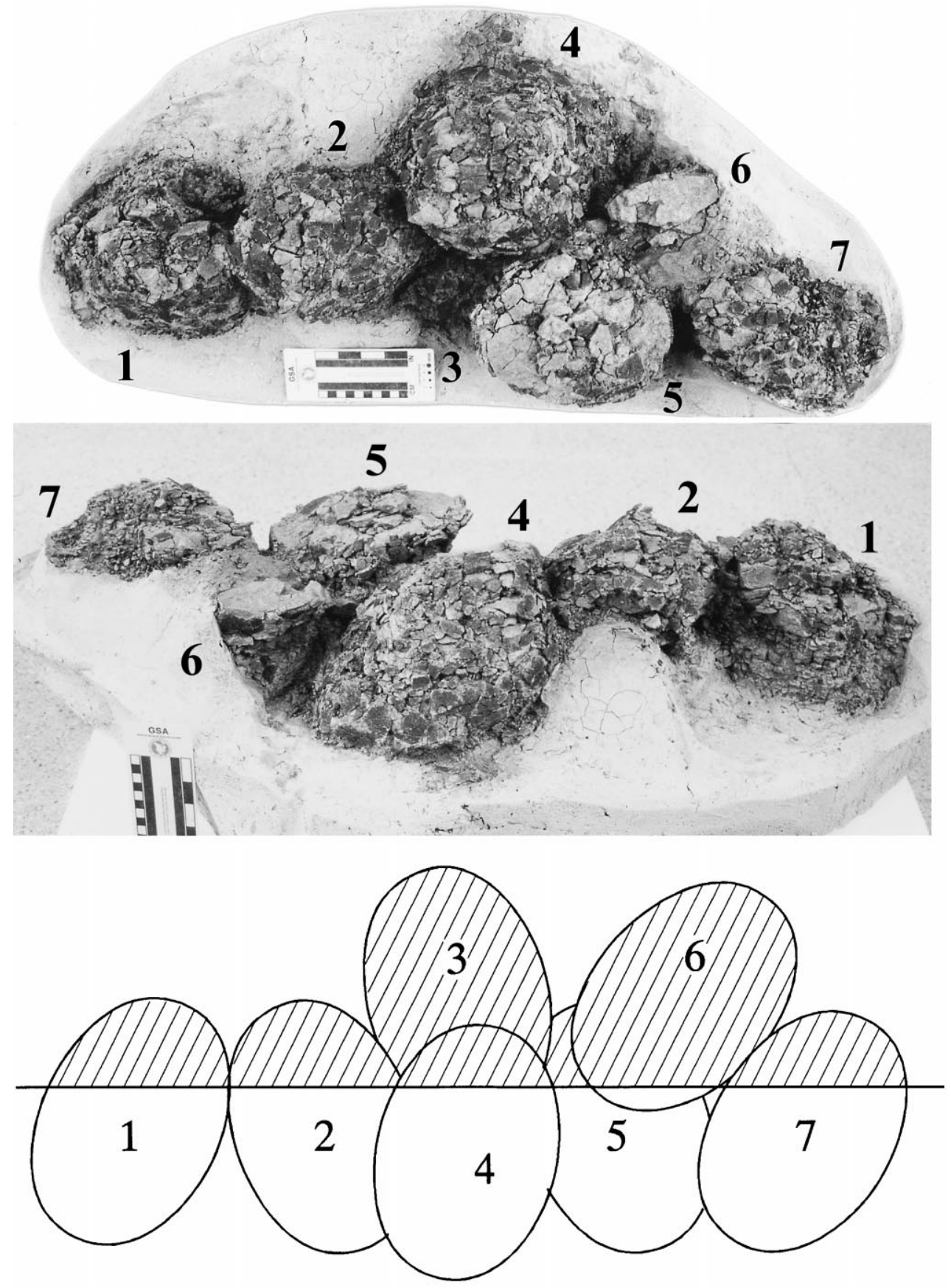

Fig. 3. Apical and lateral views of the preserved lower part of the Biscarri clutch (BIS111, photographs by Uly Martin). The original block embedded in a polyurethane matrix was disturbed by falling down during transport. Restoration was performed by reversing it upside down. Below, an interpretative scheme of the original arrangement of the eggs in lateral view. Five of the seven eggs are in one plane, with the exception of numbers 3 and 6 . The eggs were laid almost vertically, with the main axes directed towards the ground. The erosion surface is indicated; shaded areas represent lost material above it. The clutch is housed at the Museo Municipal of Isona i Conca Dellà (Lleida, Spain). 


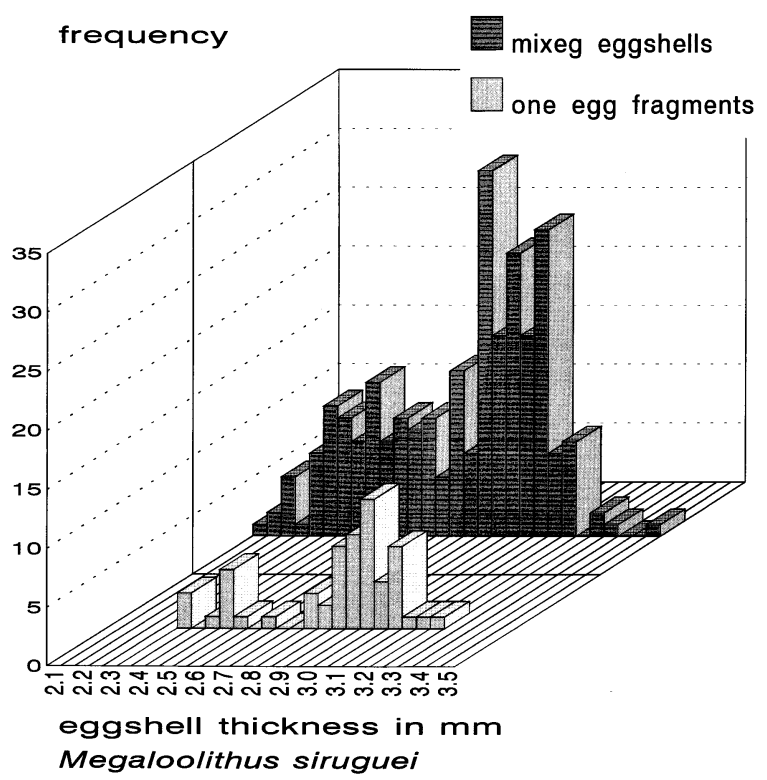

Fig. 4. Histograms of the Biscarri eggshell thickness. Note the bimodal distribution for both the whole sample and for the eggshells from a single egg. The thickest values would correspond to the eggshells from the pole areas of the ellipsoid, and the thinnest ones to the equatorial area. The variability of the eggshell thickness of an ovoid-shaped egg would have a more continuous distribution.

(Fig. 5c and d), thus increasing the permeability of the eggshell greatly (Williams et al., 1984). This feature has not been described in other dinosaur eggshell types.

Associated embryos or hatchlings have not been found yet for this oospecies. Weishampel et al. (1991) and Grigorescu (1993) attributed a similar egg type from Rumania to hadrosaurs, although the only well-documented case of hadrosaur eggs until now corresponds to a different eggshell type (prolatospherulitic: Hirsch and Quinn, 1990). Bones from both titanosaur sauropods and hadrosaurs have been documented in the Tremp basin (Lapparent and Aguirre, 1957; Brinkmann, 1984; Casanovas et al., 1987; Masriera and Ullastre, 1988). The tubospherulitic eggshell type was traditionally attributed to sauropods without direct evidence (Matheron, 1869; Dughi and Sirugue, 1957; Sahni et al., 1994). This hypothesis has been recently supported by findings of titanosaur embryos from Patagonia with eggshells attributed to Megaloolithidae (Chiappe et al., 1998), although they are not identical to the Old World Megaloolithus eggshells.

\section{Palaeobiological interpretation}

The Biscarri egg clutch preserved in tidal flat marls is the first autochthonous discovery that documents an unexpected nesting pattern for dinosaurs on the surface of wetlands. This document indicates a case of using waterlogged soil for dinosaur reproduction. No other cases of dinosaur eggs from reducing environments have yet been reported. All other cases of dinosaur eggs recorded from periaquatic deposits come from oxidized, subaereal sediments and are interpreted as nests on dry land after retreat of the shore (Sahni et al., 1994; Sanz et al., 1995). Megaloolithus siruguei eggshell fragments have been recovered from grey marls attributed to palustrine-lacustrine palaeoenvironments (Williams et al., 1984; Moratalla, 1993; Vianey-Liaud et al., 1994; Garcia, 1998), but these findings could be allochthonous fossils and do not allow one to infer the original nest habitat.

A nest setting analogous to the Biscarri dinosaur clutch is found in recent Amniota. Mound-nesting in waterlogged environments is known for crocodiles (Crocodylus porosus and Alligator mississippiensis), which nest among aquatic or even floating vegetation (Coombs, 1989). Furthermore, many aquatic birds nest on the shore, either on the surface of the soil or among riparian plants.

These modern analogues occur in periaquatic species. Terrestrial species do not nest in drowned habitats (De Deckker, 1988). Lack of predators seems to be the main advantage of periaquatic environments, but nest drowning caused by water level changes is a frequent risk in such habitats (Coombs, 1989). This type of event is probably what happened to the Biscarri clutch, as indicated by the mudstone surrounding the unhatched eggs. Contrary to the idea of Erben et al. (1979), the flooding process may preserve the clutch structure, as shown by the Biscarri clutch [see also Sahni et al. (1994). 

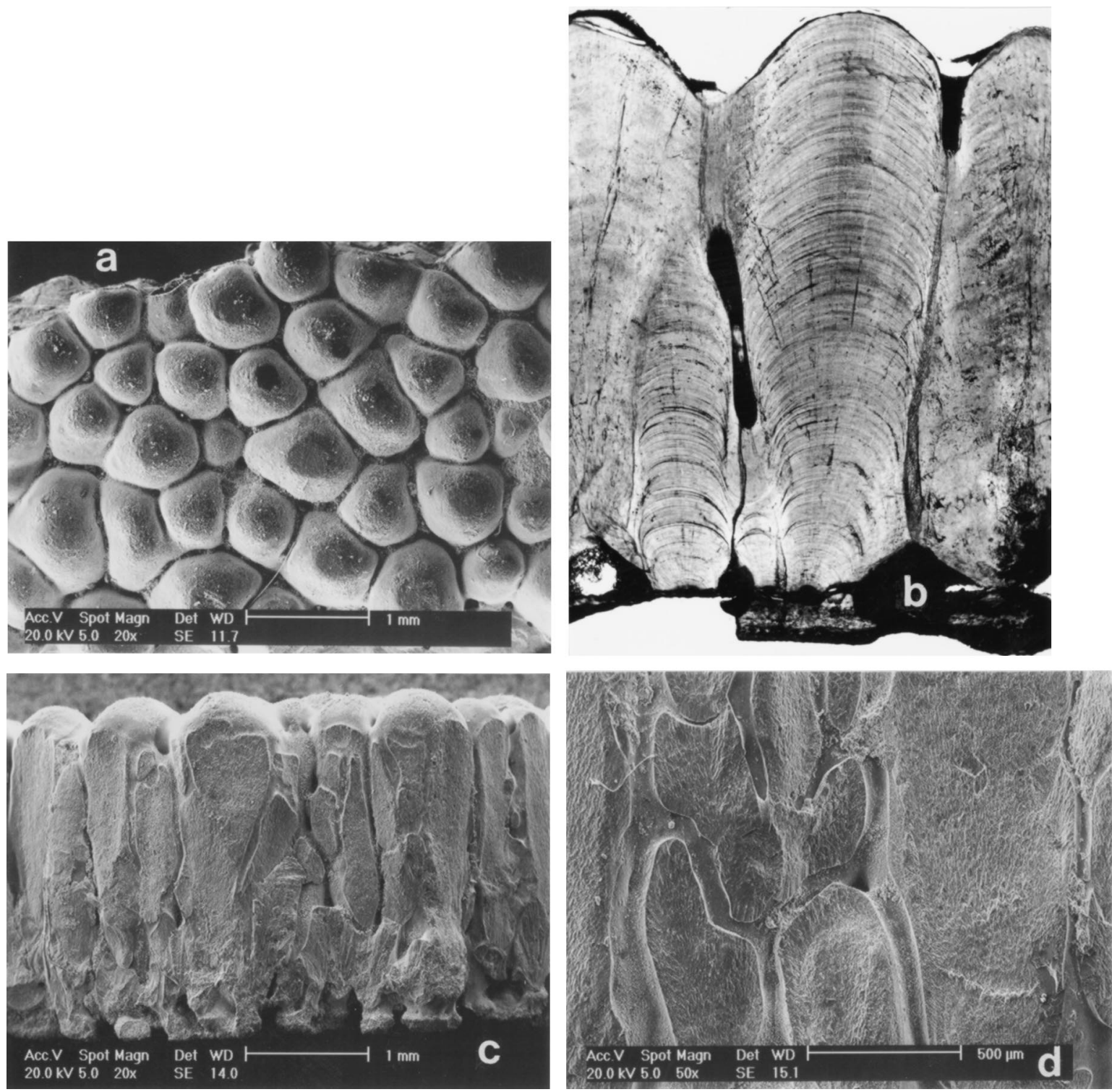

Fig. 5. Shell structure of the eggs from the Biscarri clutch. (a) Scanning electron microscope (SEM) photograph of the outer shell surface, with rounded or polygonal nodes (tubospherulitic egg-type). (b) Polarized light microscope photograph of radial thin section (courtesy of O. Kälin). The high and narrow crystal units, characteristics of the oospecies Megaloolithus siruguei, show their convex growth lines. (c) SEM photograph in radial view. (d) SEM photograph in radial view showing the canal system, a unique feature of this dinosaur eggshell type. The braided network of pore canals further increase the permeability of the eggshell.

The unusual pore canal system of the Biscarri eggshells gives additional support to the hypothesis of a riparian habitat for these dinosaurs. The complex network of pore canals found in
Megaloolithus siruguei (Fig. 5) enhanced the eggshell permeability greatly, which was already extremely high in tubospherulitic eggs (more than eight times that of avian eggshell: Seymour, 1980; 
Williams et al., 1984), and high enough to cause the dehydration of the embryo in terrestrial conditions, even in humid climate. The conductance value for $M$. siruguei has been estimated to be 12 17 times the calculated value for avian eggshells of the same size (Williams et al., 1984). A procedure to avoid the fatal loss of water was the burial of the eggs, documented for other tubospherulitic oospecies (Williams et al., 1984; Erben et al., 1979; Grigorescu et al., 1994; Sanz et al., 1995; Garcia, 1998). In the case of the Biscarri eggs, a buried hole-nest is excluded, because damp mud is an unsuitable cover for the eggs. The watersaturated sediments would smother the embryos because they could no breathe. This clutch was of neccessity lying above the sediment, probably surrounded by vegetation, as suggested by the preserved structure (see above).

However, Megaloolithidae eggs with highly porous eggshells are unsuitable for nesting on the surface, because they would be dehydrated unless they lie in a water-saturated atmosphere. Furthermore, Megaloolithus siruguei eggshells have an enhanced permeability. Dehydration in surface nests is usually avoided by covering the eggs with a mound of plants or sand, which serves also as a temperature control (Coombs, 1989). Whether or not the Biscarri clutch was covered by a plant mound, the sophisticated pore canal network of its eggshells indicates that suffocation was the main danger for the embryos, not dehydration.

The Biscarri dinosaur clutch thus shows two unusually combined palaeobiological features: evidence of surface nesting and an enhanced permeability of the eggshells. The anastomosing pore canal network in Megaloolithus siruguei eggshells could be adaptive in the case that some external pores were filled by sediment: the transverse canals would then serve as auxiliary connections between the main vertical canals, allowing gas exchange in the whole egg, thus improving the probability of embryo survival. The extremely high conductance of this egg type would function best in a habitat with a wet mud soil and water-saturated atmosphere. An extremely permeable egg enhancing the ventilation of the embryo would be adaptive for nesting in sultry, air-stagnant swamp environments.

\section{Conclusions}

The Biscarri clutch documents that some dinosaurs with Megaloolithus siruguei eggshell had paludal nesting habits and inhabited tidal flat environments. The clutch was found in coastal plain sediments interpreted as perilagoonal facies of tidal mud-flats, at the transition with a saltmarsh. The clutch with at least seven eggs was not buried, as is usual in other dinosaur clutches, but laid above the surface of a humid mud substrate, probably with plants supporting the vertical closely packed eggs. M. siruguei bears an elaborate, anastomosing pore system that made the eggshell extremely permeable. The high internal connectivity of the pore canal network could be adapted to prevent the accidental closure of pores by mud. Such a combination of surface nesting and enhanced water conductance of eggshells suggests a water-saturated, air-stagnant atmosphere, where the embryos do not have the risk of dying by dehydration but rather by suffocation. Different localities have yielded fragments of this eggshelltype from paludal sediments, but until now evidence of autochthonous fossils have been lacking. The Biscarri clutch is the first documentation of a dinosaur nesting in waterlogged habitats. Comparison with modern Amniota nesting in such habitats suggests a mode of life linked to water for this type of dinosaur.

\section{Acknowledgements}

We thank M. Álvarez-Sierra, the late R. Daams, B. López, B. Marandat, F. Ortega, P. PeláezCampomanes, E. Pérez, I. Pérez, B. Pérez-Moreno, B. Sigé and M. Vianey-Liaud for field assistance; M. Vianey-Liaud also provided useful information. Clutch restoration was undertaken by S. Gil. The Ajuntament d'Isona i Conca Dellà provided facilities for our work. We thank O. Kälin for thinsection photographs and for the critical reading of the manuscript, which benefits also from the comments of Dr M. Díaz Molina, K. Carpenter, K. Sabath and M. Vianey-Liaud. This work was supported by funds from the DGICYT (Ministerio 
Educación y Cultura, Spain, projets PB93-0353 and PB95-0398) and the Dinosaur Society (USA).

\section{References}

Ai-Agha, M.R., Burley, S.D., Curtis, C.D., Esson, J., 1995. Complex cementation textures and authigenic mineral assemblages in recent concretions from the Lincolnshire Wash (east coast, UK) driven by Fe (0) to Fe (II) oxidation. J. Geol. Soc. London 152, 157-171.

Allen, J.R.L., Pye, K., 1992. Saltmarshes - Morphodynamics; Conservation and Engineering Significance. Cambridge University Press.

Ardèvol, L., Klimowitz, J., Malagón, J., Nagtegaal, P.J.C., 2000. Depositional sequence response to foreland deformation in the Upper Cretaeous of the Southern Pyrenees, Spain. Bull. Am. Assoc. Petrol. Geol. in press.

Bakker, R.T., 1971. Ecology of the Brontosaurs. Nature 229, $172-174$

Brinkmann, W., 1984. Erster Nachweis eines Hadrosauriers (Ornithischia) aus dem unteren Garumnium (Maastrichtium) des Beckens von Tremp (provinz Lérida, Spanien). Paläont. Z. 58, 295-305.

Canudo, J.I., Torres, R.R., Barco, J.L., Cuenca Bescós, G., Ruiz-Omeñaca, J.I., 1998. New fossil remains of Sauropoda (Saurischia) in the Aptian of Spain. In: Jagt, J.W.M., Lambers, P.H., Mulder, E.W.A., Schulp, A.S. (Eds.), Third European Workshop Vert. Paleont. Maastricht, 11.

Casanovas, M.L., Santafé, J.V., Sanz, J.L., Buscalioni, A.D., 1987. Arcosaurios (Crocodilia, Dinosauria) del Cretácico superior de la Conca de Tremp (Lleida, Spain). In: Sanz, J.L. (Ed.), Geologia y Paleontologia (Arcosaurios) de los yacimientos de Galve (Teruel, Cretácico inferior) y Tremp (Lérida, Cretácico superior). Estudios Geol., Volume Extr.. Galve-Tremp, Madrid, pp. 95-110.

Chiappe, L.M., Coria, R.A., Dingus, L., Jackson, F., Chinsamy, A., Fox, M., 1998. Sauropod dinosaur embryos from the Late Cretaceous of Patagonia. Nature 396, 258-261.

Coombs, W.P., 1974. Sauropod habits and habitats. Palaeogeogr. Palaeoclimatol. Palaeoecol. 17, 1-33.

Coombs, W.P., 1989. Modern analogs for dinosaur nesting and parental behavior. In: Farlow, J.O. (Ed.), Paleobiology of the Dinosaurs. Geological Society of America Special Paper 238, 21-53.

Cousin, R., Breton, G., Fournier, R., Watté, J.P., 1994. Dinosaur egglaying and nesting in France. In: Carpenter, K., Hirsch, K.F., Horner, J.R. (Eds.), Dinosaur Eggs and Babies. Cambridge University Press, Cambridge, pp. 56-74.

De Deckker, P., 1988. Biological and sedimentary facies of Australian salt lakes. Palaeogeogr. Palaeoclimatol. Palaeoecol. 62, 237-270.

De Porta, J., Kedves, M., Solé De Porta, N., Civis, J., 1985. Palinologia del Maastrichtiense del Barranco de la Posa (Lérida, España). Problemática Regional. Rev. d'Invest. Geol. 40, 5-28.
Díaz-Molina, M., 1987. Sedimentación sintectónica asociada a una subida relativa del nivel del mar durante el Cretácico superior (Fm. Tremp, provincia de Lérida). In: Sanz, J.L. (Ed.), Geologia y Paleontologia (Arcosaurios) de los yacimientos de Galve (Teruel, Cretácico inferior) y Tremp (Lérida, Cretácico superior). Estudios Geol., Volume Extr.. Galve-Tremp, Madrid, pp. 69-93.

Dodson, P., 1990. Sauropod paleoecology. In: Weishampel, D.B., Dodson, P., Osmólska, H. (Eds.), The Dinosauria. University of California Press, pp. 402-407.

Duchaufour, P., 1960. Précis de Pédologie. Masson, Paris.

Dughi, R., Sirugue, F., 1957. Les oeufs de Dinosauriens du Bassin d'Aix-en-Provence. C. R. Acad. Sci. Paris 245, 546-549.

Erben, H.K., Hoefs, J., Wedepohl, K.H., 1979. Paleobiological and isotopic studies of eggshells from a declining dinosaur species. Paleobiology 5, 380-414.

Feist, M., Colombo, F., 1983. La limite Cretacé-Tertiaire dans le nord-est de l'Espagne du point de vue des charophytes. Geol. Méditerranée 10, 303-326.

Fiorello, A.R., 1990. First occurrence of hadrosaur (Dinosauria) remains from the marine Claggett Formation, Late Cretaceous of south-central Montana. J. Vert. Paleont. 10, 515-517.

Freytet, P., Plaziat, J.C., 1982. Continental carbonate sedimentation and pedogenesis. Late Cretaceous and Early Tertiary of Southern France. Contr. Sedimentol. 12. Schweizer Verlag, Stuttgart. $213 \mathrm{pp}$.

Garcia, G., 1998. Les coquilles d'oeufs de dinosaures du Crétacé supérieur du Sud de la France: diversité, paléobiologie, biochronologie et paléoenvironments. Thesis Université Montpellier II, $152 \mathrm{pp}$.

Gradstein, F.M., Agterberg, F.P., Ogg, J.G., Hardenbol, J., Van Veen, P., Thierry, J., Huang, Z., 1995. A Triassic, Jurassic and Cretaceous time scale. In: Berggren, W.A., Kent, D.V., Aubry, M.P., Hardenbol, J. (Eds.), Geochronology, Time Scales and Global Stratigraphic Correlation. S.E.P.M. Special Publication 54, 95-126.

Grigorescu, D., 1993. The Latest Cretaceous dinosaur eggs and embryos from the Hateg basin - Romania. Rév. Paléobiol. 7, 95-99.

Grigorescu, D., Weishampel, D., Norman, D., Seclamen, M., Rusu, M., Baltres, A., Teodorescu, V., 1994. Late Maastrichtian dinosaur eggs from the Hateg basin (Romania). In: Carpenter, K., Hirsch, K.F., Horner, J.R. (Eds.), Dinosaur Eggs and Babies. Cambridge University Press, Cambridge, pp. 75-87.

Hay, O.P., 1908. On the habits and the pose of the sauropodous dinosaurs, especially Diplodocus. Am. Natur. 42, 672-681.

Hirsch, K.F., Quinn, B., 1990. Eggs and eggshell fragments from the Upper Cretaceous Two Medicine Formation of Montana. J. Vert. Paleont. 10 (4), 491-511.

Horner, J.R., 1979. Upper Cretaceous dinosaurs from the Bearpaw Shale (marine) of South-Central Montana, with a checklist of upper Cretaceous dinosaur remains from marine sediments in North America. J. Paleont. 53, 566-577.

Horner, J.R., 1987. Ecologic and behavioural implications derived from a dinosaur nesting site. In: Czerkas, S.J., 
Olson, E.C. (Eds.), Dinosaurs, Past and Present. Natural History Museum at Los Angeles County, Los Angeles, pp. 50-63.

Iatzoura, A., Cojan, I., Renard, M., 1991. Géochimie des coquilles d'oeufs de dinosaures: essai de reconstitution paléoenvironmentale (Maastrichtien, basin d'Aix-enProvenze, France). C. R. Acad. Sci. Paris 312, 1343-1349.

Kerourio, P., 1981. Nouvelles observations sur le mode de nidification et de la ponte chez les dinosauriens du Crétacé terminale du Midi de la France. C. R. Som. Séances Soc. Géol. France 1, 25-28.

Lapparent, A.d., Aguirre, E., 1957. Presencia de dinosauridos en el Cretáceo superior de la cuenca de Tremp (prov. de Lérida, España). Notas y Com. Inst. Geol. Min. España 47, 149-152.

Liebau, A., 1971. Die Ableitung der palökologischen Systematik einer oberkretazischen Lagune. In: Oertli, H.J. (Ed.), Paléoécologie des ostracodes. Bull. Centre Res. Pau, SNPA 5, 577-599.

Liebau, A., 1973. El Maastrichtiense lagunar "Garumniense" de Isona. In: Libro-Guía XIII Col. Eur. Micropal. ENADIMSA, Madrid, pp. 87-112.

Lockley, M.G., Meyer, C.A., Hunt, A.P., Lucas, S.G., 1994. The distribution of sauropod tracks and trackmakers. In: Lockley, M.G., Dos Santos, V.F., Meyer, C.A., Hunt, A.P. (Eds.), Aspects of Sauropods Paleobiology, Gaia 10, 233-248.

López Martínez, N., Ardévol, L., 1999. Hallazgo de Dactyloidites ottoi (Geinitz 1849) en la Arenisca de Arén (Cretácico superior surpirenaico). Rev. Esp. Paleont. vol. extr. hom.. J. Truyols, 129-133.

Matheron, M.P., 1869. Notice sur les reptiles fossiles des depôts fluvio-lacustres crétacés du bassin à lignite de Fuveau. Mém de l'Academie Imperiale des Sciences, Belles-Lettres et Arts de Marseille., 345-379.

Masriera, A., Ullastre, J., 1988. Nuevos datos sobre las capas maestrichtienses con Septorella: su presencia al norte del Montsec (Pirineo catalán). Acta Geol. Hispánica 23, 71-77.

Moratalla, J.J., 1993. Restos indirectos de dinosaurios del registro español: paleoicnologia de la Cuenca de Cameros (Jurásico superior-Cretácico inferior) y paleoologia del Cretácico superior. Ph.D. Thesis Univ. Autónoma Madrid, 729 pp.

Nagtegaal, P.J.C., Van Vliet, A., Brouwer, J., 1983. Syntectonic coastal offlap and concurrent turbidite deposition: the Upper Cretaceous Aren Sandstone in the South Central Pyrenees, Spain. Sedimentary Geology 34, 185-218.

Nicolas, A., 1949. Formación y destrucción del suelo. Minist. Agricultura, Madrid. 197 pp.

Obradovich, J.D., 1993. A Cretaceous time-scale. In: Caldwell, W.G.E., Kauffman, E.G. (Eds.), Cretaceous Evolution of the Western Interior Basin, Canadian Association Special Paper 39, 379-396.

Pye, K., Dickson, J.A.D., Schiavon, N., Coleman, M.L., Cox, M., 1990. Formation of siderite-Mg-calcite-iron sulphide concretions in intertidal marsh and sandflat sediments, north Norfolk, England. Sedimentology 37, 325-343.
Rahmani, R.A., 1988. Estuarine tidal channel and nearshore sedimentation of a Late Cretaceous epicontinental sea, Drumheller, Alberta, Canada. In: De Boer, P., Van Gelder, A., Nio, S.D. (Eds.), Tide-Influenced Sedimentary Environments and Facies. Reidel, Dordrecht, Netherlands, pp. 433-471.

Retallack, G.J., 1988. In: Field Recognition of Paleosols. Geological Society of America Special Paper 216, 1-20.

Retallack, G.J., 1990. Soils of the Past. Unwin Hyman, Boston.

Riveline, J., Berger, J.P., Feist, M., Martin-Closas, C., Schidack, M., Soulié-Marsche, I., 1996. European MesozoicCenozoic charophyte biozonation. Bull. Soc. Géol. France 167, 453-468.

Rosell, J., 1967. Estudio geológico del sector del Prepirineo comprendido entre los rios Segre y Noguera Ribagorzana. Pirineos 21, 1-225.

Sahni, A., Tandon, S.K., Jolly, A., Bajpai, S., Sood, A., Srinivasan, S., 1994. Upper Cretaceous dinosaur eggs and nesting sites from the Deccan volcano-sedimentary province of peninsular India. In: Carpenter, K., Hirsch, K.F., Horner, J.R. (Eds.), Dinosaur Eggs and Babies. Cambridge University Press, Cambridge, pp. 204-226.

Sanz, J.L., Moratalla, J.J., Díaz-Molina, M., López-Martínez, N., Kälin, O., Vianey-Liaud, M., 1995. Dinosaur nests at the sea shore. Nature 376, 731-732.

Schwimmer, D.R., 1997. Late Cretaceous dinosaurs in eastern USA: a taphonomic and biogeographic model of occurrences. Dinofest Int., 203-211.

Seymour, R.G., 1980. Dinosaur eggs: the relationships between gas conductance through the shell, water loss during incubation and clutch size. Mém. Soc. Géol. France 139, 177-184.

Varricchio, D.J., Jackson, F., Borkowski, J.J., Horner, J.R., 1997. Nest and egg clutches of the dinosaur Troodon formosus and the evolution of avian reproductive traits. Nature $385,247-250$.

Verger, F., 1968. Marais et wadden du littoral français. Biscaye France, Bordeaux. 541 pp.

Vianey-Liaud, M., Mallan, P., Buscail, O., Montgelard, C., 1994. Review of French dinosaur eggshells: morphology, structure, mineral and organic composition. In: Carpenter, K., Hirsch, K.F., Horner, J.R. (Eds.), Dinosaur Eggs and Babies. Cambridge University Press, Cambridge, pp. 151-183.

Vicens, E., Ardèvol, L., López-Martínez, N., 1999. The Rudists as biostratigraphic markers: an example from the Late Cretaceous of the Southern Pyrenees, Spain. Erlanger Geol. Abh. 3, 74-75.

Weishampel, D.B., Horner, J.R., 1990. Hadrosauridae. In: Weishampel, D.B., Dodson, P., Osmólska, H. (Eds.), The Dinosauria. University of California Press, pp. 534-561.

Weishampel, D.B., Grigorescu, D., Norman, D.B., 1991. The dinosaurs of Transylvania. National Geographic Research and Exploration 7, 196-215.

Williams, D.L.G., Seymour, R.S., Kerourio, P., 1984. Structure of fossil Dinosaur eggshell from the Aix Basin, France. Palaeogeogr. Palaeoclimatol. Palaeoecol. 45, 23-37.

Zhao, A., 1979. Discovery of the dinosaurian eggs and footprint from Neixiang County, Henan Province. Vertebrata PalAsiatica 17, 304-309. 